\title{
IAMJ
}

INTERNATIONAL AYURVEDIC MEDICAL JOURNAL

\section{IMPORTANCE OF ASHTAVIDHA PARIKSHA - AS A DIAGNOSTIC TOOL}

\author{
$\underline{\text { Bhoomika Patel }}^{1}, \underline{\text { Sanjay Srivastava }}^{2}$
}

${ }^{1}$ PG Scholar, Rog Nidan \& Vikriti Vigyan

${ }^{2}$ Professor and HOD, Rog Nidan \& Vikriti Vigyan

Pt. Khusilal Sharma Government (Autonomous) Ayurveda Institute, Bhopal, Madhya Pradesh, India

Corresponding Author: 25594bhumika@gmail.com

https://doi.org/10.46607/iamj0909052021

(Published Online: May 2021)

Open Access

(C) International Ayurvedic Medical Journal, India 2021

Article Received: 08/04/2021 - Peer Reviewed: 05/05/2021 - Accepted for Publication: 15/05/2021

\section{Check for updates}

\begin{abstract}
For effective management of disease, diagnosis and prognosis are two important aspects. Clinical examination is an important tool for assessment of disease as well as condition of patient. Different types of examination depicted in Ayurveda among that Ashtavidha Pariksha viz. Nadi (Pulse), Mootra (Urine), Mala (Faeces), Jihwa (Tongue), Shabda (Speech), Sparsha (Touch), Drika (Eyes) and Akriti (Posture) an effective tool for clinical examination of patient, which was routinely used by traditional Ayurvedic practitioner, but is missing in present era. In this paper, the clinical utility of Ashtavidha Pariksha is discussed which will be helpful for scholars to use it as a diagnostic and therapeutic tool in their clinical practice.
\end{abstract}

Keywords: Ashtasthana Pariksha, Ayurveda, Examination, Diagnosis, Prognosis.

\section{INTRODUCTION}

To assess the clinical condition of patient's various methods of examination are described in Ayurveda, among them Ashtavidha Pariksha Viz. Nadi (Pulse), Mootra (Urine), Mala (Faeces), Jihwa (Tongue), Shabda (Speech), Sparsha (Touch), Drika (Eyes) and Akriti (Posture), for the first time advocated by
Aacharya Yogratnakar is one of the best and the most significant method of clinical assessment. It is a complete clinical examination of a patient which has very close resemblance with general physical examination of the patient as described in Modern Medicine. It is indeed the examination of eight aspects 
of a person to determine their health status. The body of the patient is the actual seat of disease and these eight sites represent the whole-body manifestation of underlying disease, which is the basic component for the management.

\section{Aim \& Objectives:}

1. To evaluate the clinical condition and strength of the patient.

2. To assess the diagnostic and prognostic aspect of disease with the help of Ashtavidha Pariksha.

\section{Material \& Methods:}

References of Ashtavidha Pariksha have been collected from the available literature of Ayurveda.

\section{Ashtavidha Pariksha:}

It includes the following examination. ${ }^{[1]}$

1. Nadi Pariksha (Pulse Examination)

2. Mootra Pariksha (Urine Examination)

3. Mala Pariksha (Stool Examination)

4. Jihwa Pariksha (Tongue Examination)

5. Shabda Pariksha (Voice Examination)

6. Sparsha Pariksha (Skin Examination)

7. Drika Pariksha (Eye Examination)

8. Akriti Pariksha (Examination for physical constitution)

\section{DISCUSSION}

In Ashtavidha Pariksha, examination of all eight folds are related to Pratyaksha Pramana i.e. Nadi Pariksha and Sparsha Pariksha come under Sparshnendriya Pariksha, Shabda Pariksha comes under Srotrendriya Pariksha and the other five are included under Chakshurindriya Pariksha.

Nadi Pariksha (Pulse Examination): It is the first among the Ashtasthana Pariksha and known as Jivasakshini (sign of life), its detailed description is available in Ayurveda literature and used for precise and accurate diagnosis. The status of Doshas in disease condition as well as in healthy individuals can be assessed with the help of Nadi Pariksha.

Synonyms: Dhamani, Dharani, Dhara, Snayu, Hansi, Tantuki, and Jeevan Gyan. ${ }^{[2]}$

Site and Method of Examination: Nadi Spandana is caused by the beatings of Hridaya (heart) and consequent movement of Rasa-Rakta (blood). Pulse examination is carried out through Hasta Nadi (Radial Artery) and physicians should examine the pulse of the right hand of the men and left hand of the women by using his right arm. Examination is preferably carried out early in the morning after ablution of the body. While examining the pulse, the elbow and the wrist of the patient should be slightly flexed with the fingers distended and the physician should hold the patient elbow gently with the left hand and feel the pulse with his right hand. The index finger of the physician is placed below the root of the thumb; other two fingers are placed next to the index finger. The pressure of the three examining fingers has to be uniform, it indicates the condition of the Tridosha and their Gati (Manda, Madhyama and Tikshna). The index finger (Tarjini) denotes Vata, the middle finger (Madhyama) Pitta and the ring finger (Anamika) Kapha. In Nadi Pariksha following factors are main and important: ${ }^{[3]}$

1. Spandana Samkhya (pulse rate): is described in terms of number of Nadi (pulse) per Pala of time.

2. Gunas (Qualities) of Nadi: like Ushna (warm), Sita (cold), Mrdu (soft), Kathina (hard), Tanu (thin), Sthula (thick) etc. This can easily be detected by the palpating fingers.

3. Gati (character) of Nadi: Is described to be resembling with the movement of certain animals and birds, like ${ }^{[4]}$

\begin{tabular}{|l|l|}
\hline Nadi Gati & Gati \\
\hline Nadi & Snake and Leech (i.e., Low volume and fast) \\
\hline Vataja Nadi & Frog, Crow and Crane (i.e., rate \& volume both are high) \\
\hline Pittaja Nadi & Swan, Pigeon and Peacock (i.e., high volume and low rate) \\
\hline Kaphaja Nadi & Snake and Swan \\
\hline Vata-kaphaja & Snake and Frog \\
\hline Vata-pittaja & Monkey and Swan \\
\hline Pitta-kaphaja & Woodpecker (with frequent gaps, variable rate and volume or irregular) \\
\hline Sannipataja & \\
\hline
\end{tabular}




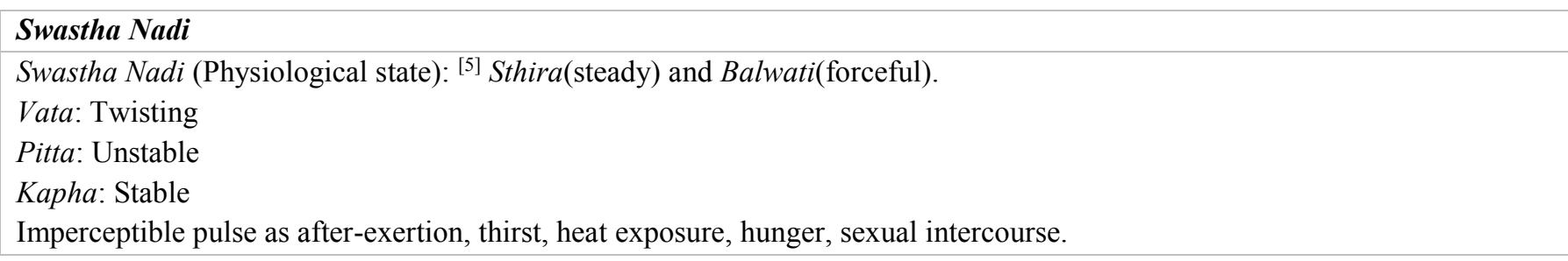

\begin{tabular}{|c|c|}
\hline \multicolumn{2}{|c|}{ Vikrata Nadi (Pathological state) ${ }^{[4]}$} \\
\hline Pathological condition & Nadi Gati (pulse movement) \\
\hline Mandagni & Manda (slow) \\
\hline$A m a$ & Gambheera \\
\hline Jwara & Ushna, Gambheer, Vegavati \\
\hline Kama, krodha & Vegavati (rapid) \\
\hline Chinta, Bhaya & Kshina (weak) \\
\hline Deeptagni & Laghu and Vegavana \\
\hline Rakta Dosha & Ushna, Gurvi (heavy) and Sama \\
\hline Kshudhita & Chanchala (unstable) \\
\hline Tripta & Sthira (stable) \\
\hline Asadhya vyadhi & Kampana (vibration) and spandana (pulsation) \\
\hline
\end{tabular}

Nadipariksha Nishedhakala (Contraindication):

Nadi will be misleading or incorrect if done after the patient has taken food, exercise, bath, intoxicants, intercourse and sleep or when afflicted with hunger, thirst, anger, grief, worry etc.

Mootra Pariksha (Urine Examination): Urine is the end product of metabolism by billions of human cells and the body chemistry, nutrient intake, fluid balance, blood pressure and the state of health are key elements in determining the nature of urine. Among the Ashtavidha Pariksha, Mootra Pariksha is one which proves to be an important aid in diagnosis and prognosis. Taila Bindu Pariksha is a part of Mootra Pariksha which can be used as a tool for assessing the prognosis and severity of diseases to plan the treatment. The purpose of urine examination is to determine the Tridoshika manifestations in the body through its volume, frequency, colour, consistency, smell and taste etc. in diagnosis of disease as well as assessing the healthy condition.

\section{Characters of Urine vitiated by Doshas:}

Vata: Pandu varna (pale yellow colour)/unctuous appearance

Pitta: Rakta varna (reddish colour)/oil like appearance

Kapha: Phenayukta (foamy/muddy appearance) Dwandaj: Mixed features as per dominancy of Doshas Sannipataja: Krishna (blackish colour)

\begin{tabular}{|l|l|}
\hline Urine appearance in certain diseases & \\
\hline Disease's condition & Urine appearance \\
\hline Ajeerna & Tandulodak (rice water like) \\
\hline Nava jwara & Dhumra varna (smoky) and polyuria \\
\hline Jeerna jwara & Reddish yellow \\
\hline Vatapittaja jwara & Smoky and hot \\
\hline Vatakaphaja jwara & Whitish with budbudabhama (bubbles) \\
\hline Kaphapittaja jwara & Kalusa varna (dark coloured blood mixed) \\
\hline Sannipataja jwara & Mixed coloured \\
\hline
\end{tabular}


Taila Bindu Pariksha: Vasavarajiyam had mentioned the use of Til Taila for Taila Bindu Pariksha. The physician should wake up the patient early in the morning, around 4 o'clock; first midstream urine sample should be collected in a wide mouth, plastic or glass, air tight, sterilized disposable container and examined for detecting various abnormalities in it for diagnosing the underlying disease.
The urine is kept in a clean vessel and with the help of Tran(rod) or a dropper, instil one or two drops of Tila Taila into the vessel. The changes of the oil drop on the surface of urine should be carefully observed viz. Time of spread, Direction of spread, Shape, Pattern of oil on spreading over urine, and then we can assess type of Dosha Vikara, curability or non-curability of disease. ${ }^{[6]}$

Taila Bindu appearance (shape of urine drops)

\begin{tabular}{|l|l|}
\hline Dosha & Shape \\
\hline Vata & Snake \\
\hline Pitta & Umbrella \\
\hline Kapha & Pearl \\
\hline
\end{tabular}

Disease condition observed by Shape of spread oil drop

Shape of spread oil drop

Swan, pond, lotus, elephant, umbrella, gate or building

Disease condition

Plough, tortoise, buffalo, honeycomb, sword, crossroad, a man without head

Sadhya

Asadhya

\section{Disease condition observed by position of oil drop}

Oil position

If oil drop spreads fast over urine

If oil drop spreads very slowly

If oil drop settles down at the bottom of pot

Disease condition

Sadhya

Kastasadhya

Asadhya

Prognosis observed by the direction of movement of the oil drop

Direction

Movement towards East

Movement towards West

Movement towards North

Movement towards

Movement towards Ishana Angle

Movement towards Aagneya and Nairatya Angle

Movement towards Vayavya Angle

Mala Pariksha (Stool Examination): Mala (Purisha) is one of the important waste products of the body being the Kitta of Ahara (food), hence it is a diagnostic method generally in all diseases and especially in disorders of Annavaha Srotas and Purishvaha Srotas system. In Ayurvedic texts examination of stool is limited mainly up to the examination of physical characteristics such as Rashi, Swarupa, Varna, Gandha. Besides these, a specialized

\section{Prognosis}

Quick recovery

Patient will get happiness and healthy

Patient will be healthy very soon

Indicate fever and gradual recovery

Patient will die within one month

Patients' death is certain

Patient will die soon

technique Viz. Jala Nimajjana Purisha Pariksha has been indicated to identify Sama Nirama condition of Mala. ${ }^{[7]}$

Jala Nimajjana Purisha Pariksha: This is the only objective method which was used in ancient times to detect the presence of Ama in stool. The examiner should take a wide mouth glass vessel and fill it with clean water. Place some faecal matter over the surface of water. If the stool is very hard and sinks to the 
bottom, it indicates the presence of Ama. If it is indicates Ama is absent in stool.

filamentous and floats over the water surface, it

\begin{tabular}{|l|l|}
\hline Mala Lakshana in different Dosha Vikara & \\
\hline Dosha Vikara & Mala Lakshana \\
\hline Vata Vikara & Dridha (hard) and Shushka (dry) \\
\hline Pitta Vikara & Pitta (yellowish) \\
\hline Kapha Vikara & Shukla (white) \\
\hline Sannipataja & Shyama, Trutita, Pittabha, Baddha, Shweta \\
\hline Vata Kapha & Kapisha (brown) \\
\hline Pitta Vata & Baddha Trutita (quite fragmented), Peeta-Shyama (yellowish-black) \\
\hline Pitta Vata & Peeta-Shweta, Ishat Sandra (semisolid), Pichhila (slimy) \\
\hline
\end{tabular}

\begin{tabular}{|l|l|}
\hline \multicolumn{2}{|l|}{ Mala Lakshana in different diseased condition } \\
\hline Diseased condition & Mala Lakshana \\
\hline Jalodara (Ascites) & Sita (white), Puti gandha (bad stench) \\
\hline Shakhashritta Kamala (obstructive jaundice) & Tilpishtawat (pale /clay colour) \\
\hline Kumbha Kamala & Krishna Varna (malena) \\
\hline Mrittikabhakshanjanya Pandu & Raktapuyakuta (mixed with blood and mucus) \\
\hline Kshaya (Phthisis) & Shyama varna \\
\hline Ama condition & Yellowish with pain in lumbar region \\
\hline Jirna Mala & Foul smell, cold, hard stool \\
\hline Sannipataj Asaadhya Atisar. & Mamsambu Sadrisham (dark reddish blackish) \\
\hline Tikshnaagni & Lumpish dry \\
\hline Mandaagni & Drava (loose) \\
\hline Asadhyavyadhi & Stinks too much, Shines like moon beam \\
\hline
\end{tabular}

Jihwa Pariksha (Tongue Examination): ${ }^{[8]}$ The variety of clinical information which help in the tongue is the index of the stomach, implying its importance in the diagnosis of digestive disorders. Tridoshika diagnosis of a disease. It also manifests the The examination of the Jihwa (Tongue) reveals a

\begin{tabular}{|l|l|}
\hline \multicolumn{2}{|l|}{ Tongue appearance in predominance of Doshas } \\
\hline Predominance of Doshas & Tongue appearance \\
\hline Vata & Sita (Cold), Khara (Rough), Sphutita (Fissures) \\
\hline Pitta & Rakta (Red), Shyam (Dark Blue) \\
\hline Kapha & Shubhra (White), Picchila (Excessively Greasy) \\
\hline Sannipataj & Black, Kantaka (Thorny), Dry \\
\hline
\end{tabular}

\begin{tabular}{|l|l|}
\hline Conditions of Jihwa in Various Diseased Conditions \\
\hline Manifestation of Tongue & Disease condition \\
\hline Pale and white & Kaphadhikya \\
\hline Pandu & Anaemia \\
\hline Pita (Yellow) & Pittadhikya, Jaundice \\
\hline Haridra (Green) & Halimaka (chlorosis) \\
\hline Nila (Blue) & Respiratory disorder \\
\hline Krishna (Black) & Renal disorders, licking of iron contain medicine \\
\hline Atirakta (Angry Red) & Pittajjwara (Hyperpyrexia), Tikshnagni (Hyperthyroidism), Raktavrddhi (Polycythemiavera) \\
\hline
\end{tabular}


Shabda Pariksha (Voice Examination): Shabda Pariksha is the examination of the various sounds produced by the different organs of the body; hence an examination of the normal and abnormal sounds will be advantageous to arrive at correct diagnosis. The voice will be healthy and natural, when the Doshas are in a balanced state. ${ }^{[9]}$

Voice appearance in Various Conditions

Various Conditions

Kapha Vikrti / Ama / Medaja Vikara

Pitta Vikrti

Kapha Vikrti

Voice appearance

Guru Svara (heavy, thick and deep)

Sphuta (clear), sharp

Dry, hoarse and broken.

The conditions producing change in speech and sound are like MinMina i.e., nasal speech and monotonous in case of extra pyramidal lesions, Gadagada (stammering/spastic speech) due to brain trauma (indicating UMN lesions), Swarbheda (hoarseness of voice) may leads to chronic irritation of the larynx caused by smoking or excessive alcoholism.

Sparsha Pariksha (Touch Examination): This is a method to understand the condition of the various parts of the body in respect of their normal or abnormal Gunas (qualities). ${ }^{[10]}$
Palpation can be compared with the Sparsha Pariksha of Ayurveda, which used for assessing the state of organs and tissue examination of skin like i.e., roughness of the skin in Anaemia or malabsorption syndrome, rashes over skin or discharge from skin in Eczematous dermatitis, skin and extremities are hot in fever and are found to be cold in case of circulatory failure/cardiac arrest. In this way tactile examination (Sparsha Pariksha) plays an important role in diagnosis of disorder.

\begin{tabular}{|l|l|}
\hline \multicolumn{2}{|l|}{ Sparsha Pariksha in predominance of Doshas } \\
\hline Predominance of Doshas & Sparsha observation \\
\hline Vata & Sita Sparsha (cold), Ruksha (dry) \\
\hline Pitta & Ushna Sparsha (hot) \\
\hline Kapha & Sita Sparsha (cold), Picchila (greasy) \\
\hline
\end{tabular}

Drika Pariksha (Eye Examination): Expressions of the eyes reflect the health status of the entire body. The examination of eyes provides more information about the condition of the Doshas and the underlying disease. ${ }^{[1]}$

\begin{tabular}{|l|l|}
\hline Drika Pariksha in predominance of Doshas \\
\hline Predominance of Doshas & Drika observation \\
\hline Vata & Ruksha (dry), Dhumra (smoky), Roudra (terrifying), Chala (unsteady), Antarjwala (glows inside) \\
\hline Paitta & Dipa dwesha (fear from light), Santapta (burning sensation), Pita Varna (yellowish colouration) \\
\hline Sannipataja & Jalardra (moist by water), Jyotihina (lustreless), Snigdha (greasy), Shweta (whitish) \\
\hline & $\begin{array}{l}\text { Rakta (red), Kalusa (dirty), Asita (black), Bhishana (horrifying), Nirbhugna (oblique) and } \\
\text { Nisprabha (lustreless), Tandra-Moha Yukta (stuporous look). }\end{array}$ \\
\hline
\end{tabular}

In clinical condition like Anaemia (Pandu Roga) the colour of eyes (sclera) is changed to yellowish white, deep yellow conjunctiva in case of jaundice (Kamala), In case of excessive blood loss, purgation and starvation eyes results sunken, prominent or bulging eyes can be seen in thyrotoxicosis etc. ${ }^{[12]}$
Akriti Pariksha (Facies \& Overall Appearance): Akriti Pariksha means the examination of the external features of the whole body. In Ayurvedic texts it may be considered under Deha Prakriti Pariksha, Ashta Nindita Purusha (unhealthy physique), Vishamasana Sayana (abnormal posture, gait), Sahaja Vikritis 
(congenital deformities) and Mukha Bhava (facial expression) ${ }^{[13]}$.

\begin{tabular}{|c|c|}
\hline \multicolumn{2}{|c|}{ Akriti Pariksha in predominance of Doshas } \\
\hline Predominance of Doshas & Akriti observation \\
\hline Vata & $\begin{array}{l}\text { Vibhu, Ashukari, Balvana, prone to many diseases, split hair and dry skin with Dhusara } \\
\text { Varna, dislikes cold, Pralapa, unstable Dhriti, Smriti, Buddhi, Cheshta etc. }\end{array}$ \\
\hline Pitta & Hungry and thirsty, fair in colour, brave, Swabhimani, less hair \\
\hline Kapha & Jalardra (moist by water), Jyotihina (lustreless), Snigdha (greasy), Shweta (whitish) \\
\hline Sannipataja & Saumya, snighdha, well-built body and joints, tolerant to hunger, thirst, hardship, hot sun \\
\hline
\end{tabular}

\section{CONCLUSION}

Diagnosis as per Ayurveda is not merely naming the disease, but identification of the imbalance of trienergies (Doshas). These eight factors are excellent ways for judging the imbalance of tri-energies.

It is advisable that 'Diagnosis should precede treatment wherever possible. Ashtavidha Pariksha was designed in such a way that these were very much applicable in leading to the diagnosis and prognosis of a certain disease. It helps the physician to decide if he can handle the case or if it would be wise enough to refer the case to related specialties and helps in planning a comprehensive treatment protocol.

One can draw a conclusion on diagnosis of a particular disease and can start management accordingly, on the basis of various clinical observations described in Ashtasthan Pariksha.

\section{REFERENCES}

1. Vaidya Laxmipati Sastri, Yogaratnakara with vidyotani Hindi commentary, Varanasi Chaukhambha Prakashana; Reprint Edition 2017, p - 5.

2. Tripathi Indradeva and Tripathi Dayashankara, (2007), Yogaratnakara, Krishnadasa Ayurveda Series 54, Varanasi, Chaukhambha Ayurveda Prakashana, $\mathrm{p}-5$.

3. Prof. K.R. Srikantha Murthy, Clinical methods in Ayurveda, Varanasi Chaukhambha Orientalia; Reprint Edition 2013, p $658-659$.

4. Tripathi Indradeva and Tripathi Dayashankara, (2007), Yogaratnakara, Krishnadasa Ayurveda Series 54, Varanasi, Chaukhambha Ayurveda Prakashana, p - 7 .

5. Vinay Kumar, Principle of ayurvedic therapeutics, Srisatguru Publication, First Edition1995, p -113.
6. Vaidya Laxmipati Sastri, Yogaratnakara with vidyotani hindi commentary, Varanasi Chaukhambha Prakashana, Reprint Edition 2017, p - 10.

7. Vaidya Laxmipati Sastri, Yogaratnakara with vidyotani Hindi commentary, Varanasi Chaukhambha Prakashana, Reprint Edition 2017, p - 12.

8. Vaidya Laxmipati Sastri, Yogaratnakara with vidyotani Hindi commentary, Varanasi Chaukhambha Prakashana, Reprint Edition 2017, p -14.

9. Prof. K.R. Srikantha Murthy, Clinical methods in Ayurveda, Varanasi Chaukhambha Orientalia, Reprint Edition 2013, p 691 - 693.

10. Vaidya Laxmipati Sastri, Yogaratnakara with vidyotani Hindi commentary, Varanasi Chaukhambha Prakashana, Reprint Edition 2017, p - 16.

11. Vaidya Laxmipati Sastri, Yogaratnakara with vidyotani Hindi commentary, Varanasi Chaukhambha Prakashana, Reprint Edition 2017, p -17.

12. Katwal Savita, Chandresh Renuka, Srivastava Akhilesh, Sharma Dalip. ASHTAWIDHA PARIKSHA: AN AYURVEDIC DIAGNOSTIC TOOL, Volume III Issue V 2017.

13. Tripathi Indradeva and Tripathi Dayashankara, Yogaratnakara, Krishnadasa Ayurveda Series 54, Varanasi Chaukhambha Ayurveda Prakashana 2007, p -11 .

\section{Source of Support: Nil \\ Conflict of Interest: None Declared}

How to cite this URL: Bhoomika Patel \& Sanjay Srivastava: Importance Of Ashtavidha Pariksha - As A Diagnostic Tool. International Ayurvedic Medical Journal \{online\} 2021 \{cited May, 2021\} Available from: http://www.iamj.in/posts/images/upload/1000_1006.pdf 